\title{
Energy researchers fight for their survival
}

Fort Worth. Energy research in Texas is at a crossroads. Gone are the good old days when oil and gas fuelled the state economy and provided steady jobs for geologists and other researchers. In fact, the state's business base has diversified and energy's economic contribution has fallen so much that the Texas Employment Commission has reclassified oil and gas as a 'declining industry.'

Most large oil companies have made deep cuts in their Texas work forces in reaction to falling oil and natural gas prices and declining demand for crude. In recent years, thousands of scientists in the laboratory received pink slips along with the roughnecks working on the rigs.

Geophysical scientists involved in exploration have fared even worse. With new discoveries in the lower 48 states increasingly rare, US companies looking for new oil are most likely to do so abroad, offshore or in Alaska.

As a result, the private sector research laboratories that once fed the nation's largest oil-producing state are in transition. They are shrinking in size, and their focus is changing. They are trying to get more oil from existing fields by using sophisticated computer-based technologies such as imaging and simulation, and they hope that the same technology will also allow them to do it faster, cheaper and more efficiently.

Because oil companies

have less money to spend, they are also trying to make every research dollar count - through joint ventures and industry consortia as well as joint programmes with university research centres. "The industry needs to be more intelligent about how to spend its research dollars", says Michael Wiley, a vice president at Atlantic Richfield Co. and manager of ARCO's exploration and technology operation in Plano, a Dallas suburb.

Oil \& Gas Journal, an energy industry trade publication, estimates that US companies will spend $\$ 32,500$ million on domestic energy projects this year, compared with $\$ 34,600$ million in 1991 . The journal's annual survey found that exploration and production budgets, a subset that accounts for most spending on research, will reach a fiveyear low this year.

Although universities in Texas operate a number of energy research centres, private industry has historically driven the state's oil and gas research. At the same time, however, those companies finance mostly applied research. They leave basic research to universities, national research laboratories and industry consortia. Even though

research in the private sector is proprietary in nature, much of it eventually becomes public through technology transfer.

That is why the latest research figures worry industry officials such as Bill Fisher, director of the Bureau of Economic Geology at the University of Texas at Austin. The bureau is the state's main energy research arm, housing the State Geological Survey and emphasizing applied research in oil and gas. "We're losing a lot of very experienced talent in the industry," Fisher laments.

Some of the displaced geologists and petroleum engineers are finding jobs in related fields that also involve geophysical

\section{IMAGE \\ UNAVAILABLE FOR COPYRIGHT REASONS}

\section{Top, ARCO geologists in Houston study maps of oil fields; left, a compu- terized image of an underground formation.}

science-hydrology or environmental protection against underground waste storage tanks, for example. Others have taken jobs abroad, left the volatile industry or continue to look for work.

Historically, oil and gas research in Texas has concentrated on exploration to find and develop new fields. But the greatest potential for future oil production in Texas may be recovering more oil from known fields.

The bureau estimates that existing Texas fields contain 170,000 million barrels of oil. Industry has recovered only 35 per cent, and sent most of it to refineries. About a third of the remaining oil is accessible by conventional means and resides mostly in geologically complex reservoirs in the so-called Permian Basin of West Texas.

Removing this oil depends on advanced geophysical detection technology and advanced geophysical modelling, Fisher says. Recovery of the rest will require advanced extraction technology. Such technology could double the amount of oil recovered in the state from existing fields, Fisher reported last year, and nearly double the existing volume of natural gas.

Using such technology could help keep oil and gas a vital industry in Texas. Their contribution to the gross state product has declined in the past 30 years from 20 per cent to about 15 per cent. New technology could prevent it from slipping further, according to the Bureau of Economic Geology.

ARCO's exploration and technology research group, which supports all of ARCO's operations, has long operated an enhanced recovery programme using such technologies as advanced simulation. "We're probably doing more in integrating that technology more closely with geoscientists than in the past," Wiley said. "Everything we do today is cross-disciplinary."

Medium-sized independent companies and universities are likely to play a larger role in researching and developing such advanced technologies. Many companies have been funding joint research programs at universities for years, and the idea is expected to become more popular.

Research centres such as the Bureau of Economic Geology and trade groups such as the Texas Independent Producers \& Royalty Owners have joined to help transfer more technology to smaller companies that lack money to carry out research. The two are teaching smaller companies how to use computer-based technology to remain competitive - or at least to survive the latest wave of contraction.

Industry would also like the state government to fund more energy research and find new markets for energy-related products. The state now spends only about $\$ 5$ million annually on oil and gas-related research. But an increase is not likely until the state's budget problems ease.

Fisher says annual research expenditures on Texas energy resources must rise from the current $\$ 50$ million to $\$ 300$ million annually in five years to take advantage of the state's remaining oil and gas resources. That would include an increase in state spending to $\$ 30$ million annually and a jump in federal spending from $\$ 10$ million to $\$ 200$ million annually with a quarter of the money spent in Texas. Raising federal spending to that level would still equal only 0.3 per cent of the current trade deficit from imported oil, Fisher estimates.

Although some energy industry executives say such generous outlays are just wishful thinking, Fisher and other state energy officials say that an tax credit incentive, now being debated, could finance much of the increase. The outcome of that campaign could help to determine the shape and make-up of the Texas economy well into the next century. Recognizing the industry's need for continued technology advances, says Fisher, would allow oil and gas to remain a vital part of the New Texas.

Kathryn Jones 